The Labore Journal of Economics

$10: 2$ (Winter 2005) pp. 55-74

\title{
A Comparison of Domestic Vs Foreign Banks Using Stochastic Frontier Approach
}

\section{Adiqa Kiani*}

\section{Introduction}

In a globalized world in which the structures of the financial service industries are changing rapidly and becoming more and more competitive, the cost efficiency of financial institutions along with better quality of service have assumed crucial significance for their long-term sustainability. Hence, the nature of efficiency of financial institutions will determine the prospects of their success in meeting the challenges of a globalized world.

The commercial banks in Pakistan are also facing the challenges of increased competition from foreign commercial banks while their operations over the years have also been called into question. However, the literature, which deals with questions of cost efficiency of commercial banks in Pakistan in a professional manner is scant. The information on relative technical efficiency of commercial banks, if available, can be helpful in designing policy for this important sector.

The fact of the matter is that Pakistan's banking sector and financial institutions are under a great deal of pressure to maintain their profitability. The banks' difficulties relate to inadequate productivity, high intermediate costs of funds, huge expenditure on establishment, over-staffing, large number of loss making branches and management of funds [Klien 1992].

In addition, there is high incidence of loan default. The stuck-up loan portfolio of banks/DFIs has been a source of major concern for the overall financial health of the banking system in the country. Defaulted loans, which were Rs. 146.1 billion as of $30^{\text {th }}$ June 1998 , have been marginally reduced to Rs. 134.8 billion in December 1998 [Government of Pakistan (1999b)].

Economic efficiency can be decomposed into two basic components: technical efficiency and price efficiency (allocative efficiency). A firm is said to

\footnotetext{
* Assistant Professor, Department of Economics, Federal Urdu University of Arts, Science \& Technology, Islamabad.
} 
be technically more efficient than another firm if it can produce more output using a given amount of inputs as compared to another firm [Yotopulas and Lau 1973]. In other words, it implies that quantifying differences in technology ${ }^{1}$ can capture differences in technical efficiency. A profitmaximizing firm is regarded as an allocatively efficient firm where profit maximization means that the marginal cost of the firm will be equal to marginal revenue of the firm. If there are differences in the economic efficiency of two firms then it might be either because of technical or price inefficiency.

Technical efficiency has been cited widely as one of the major sources of change in the financial sector industry (Anderson, 1993). However, only a few studies have attempted to investigate the relative technical efficiency especially for the banking sector of Pakistan. This study has two distinct goals. First, investigating the relative technical efficiency of commercial banks operating in Pakistan including Pakistani banks and foreign banks. Second, to make comparisons between them using the stochastic cost frontier approach. This technique can show how efficient cost varies among different banks with service provision, and how actual cost departs from efficient cost. Such a comparison is of particular interest because in this way we will be able to analyze the relative efficiency of banks. In addition, we can also analyze year wise relative performance of the banking sector in Pakistan.

The organization of the Study is as follows. Section 1.2 reviews the existing empirical studies on the banking sector. Section 1.3 discusses the methodology of our model, sources of data, specification of inputs and output of the banking sector and construction of different variables. Section 1.4 gives the interpretation of the results on the cost structure of the banking sector. Finally, Section 1.5 consists of summary and concluding remarks.

\section{Empirical Studies on the Banking Sector}

There are various approaches to the measurement of efficiency discussed above which have been applied to measure technical efficiency of banks. In this section, we present a review of these studies.

Aly et al. (1990) analyzed the nature of technical, scale and allocative efficiency of banks in the United States. They used the non-parametric technique to estimate overall allocative and technical efficiency for the year

\footnotetext{
${ }^{1}$ In the perspective of banking efficiency, technology implies computers, the new service products that banks may offer. ATM (Automatic Teller Machine), Credit cards, travelers' cheques and other money market accounts are included in the new service products.
} 
1986 of 322 banks and found a low level of overall efficiency. On average, the banks were found to be scale efficient while technical efficiency was found to be negatively related to product diversity, and positively related to the extent of urbanization.

Ferrier and Lovell (1990) studied cost efficiency in the US banking sector. They compared the ability of the econometric and linear programming techniques to reveal the structure of cost efficiency in the banking sector. Their parametric results show that technical inefficiency raises cost by $9 \%$, on average, while the allocative inefficiency raises cost by $17 \%$. The non-parametric results showed that technical inefficiency was $16 \%$ on average while allocative inefficiency raises cost by $5 \%$ and follows a decreasing trend as the bank size increases.

Yuergert (1993) made important contributions to the literature on efficiency in financial services. First, he showed estimates of fixed error cost frontier in which the variance of both the normal and gamma distribution can vary with firm size. Second, he extended the literature on life insurance scale and product mix economies by incorporating and measuring $\mathrm{X}$ inefficiency ${ }^{2}$. Third, comparison of normal and gamma estimates with other methods explained few drawbacks of gamma distribution. Yuergert used cross section data of 805 companies for the year 1989 and the translog cost function in estimation. His results showed that there was a substantial amount of X-inefficiency in the industry, but the difference across firm's size was insignificant.

Zardkoohi and Kolari (1994) analyzed empirical estimates of scale and scope economies for 615 branch offices representing 43 saving banks in Finland for the year 1988. A standard translog cost analysis was used to obtain estimates of both economies of scale and scope for different asset sizes. Their result suggested that there are economies of scale for individual branch offices.

Favero and Papi (1995) analyzed efficiency of the Italian banking sector. They used both parametric and non-parametric methods to make a comparison between these two approaches on a sample of 174 Italian banks for the year 1991. Banks included in that sample cover approximately $80 \%$ of the total deposits in Italy and they found that the Italian banking industry features high variability in all the cost and profitability indicators.

\footnotetext{
${ }^{2} \mathrm{X}$-inefficiency is defined as deviation from the efficient frontier. That is differences in managerial ability to control costs or maximize revenue to be greater than the cost effects of the choice of scale and scope of production.
} 
Musleh-ud-Din et al. (1996) examined the scale and scope efficiency of the Agriculture Development Bank of Pakistan. Using the production approach to measuring the bank's costs and outputs, a translog cost function is estimated. They used the survey data of 341 branches of the ADBP for the years 1991-1995. Their result showed that the bank's production technology exhibits both overall and product-specific economies of scale. Second, even though bank branches in all size categories enjoy economies of scale, the extent of such economies is larger for branches operating at a smaller scale of production. This implies that as the bank branches grow larger in size in terms of both loan and deposit accounts, they move closer to attaining constant returns to scale. Third, the marginal costs of servicing both loan and deposit accounts decline, as bank branches grow larger in size in terms of either the number of loans or the number of deposits. Finally, their result showed the bank's production technology is characterized by cost complementarity, i.e., there exist scope for cost savings through the joint production of loans and deposit accounts.

Chang et al. (1998) conducted a comparative analysis of productive efficiency of foreign-owned multi-national banks (FOMNB) and US-owned multinational banks (USMNB) operating in the US for the years 1984-1989. They used translog stochastic cost frontier approach in their analysis. Their results indicate that average inefficiency score of the US multi-national banks at $21.0 \%$ was significantly lower than the average inefficiency score posted by the foreign owned multi-national banks at $27.0 \%$. The most inefficient banks were FOMNBs with foreign ownership exceeding 50\%. They found that the larger the foreign presence in terms of ownership, the more inefficient the bank was.

Altunbas et al. (1999) estimated the impact of technical change on the costs of European banks using the stochastic cost frontier. The data set of 3779 banks, based in 15 European countries, for the year 1989 to 1996 was used. Technical change is decomposed into pure, scale augmenting and non-neutral components. The results suggest that the annual rate of total cost reduction, attributable to technical change, to be very strongly correlated with the bank size. For representative banks operating with all outputs and inputs at their 1996 sample mean values within each size bank, the 1996 rates vary from $0.6 \%$ for the smallest banks, through $1.2 \%$ and $4.9 \%$ for the two intermediate size banks, to $6.7 \%$ for banks in the largest size bank.

The literature reviewed in this section shows that considerable advance has been made in the literature on banking efficiency in developed countries. However, no such effort has been made to estimate the relative 
efficiency of commercial banks in Pakistan. Non-parametric linear programming technique has remained popular in the existing studies. However, one of the major shortcomings of the non-parametric DEA models is said to be their non-stochastic nature. Consequently, the efficiency scores obtained from these models may be contaminated, depending upon the nature and extent of the statistical noise in the data sets. Thus, development of stochastic DEA models is crucial for research on the DEA frontier. Recently, Land, Lovell, and Thore (1988), have developed stochastic DEA models but without much success. The problem seems to be the substantial requirements to implement these models, which creates a practical difficulty in the use of this approach. The biggest advantage of the stochastic frontier approach is that it introduces a disturbance term representing random error and exogenous shock beyond the control of the production unit. The computation involved is not trivial, but it does not seem to have hindered the empirical implementation of the model.

\section{Methodology and Data}

\section{a. Methodology and Estimation Procedure}

This study uses a methodology, which allows for the calculation of the technical efficiency of a bank assuming allocatively efficient banks. Basically, this involves the construction of a best practice cost frontier through the use of stochastic cost frontier. The technical efficiency of each bank is then measured relative to this frontier.

To estimate technical efficiency of commercial banks in Pakistan, we employed the stochastic cost frontier approach of Aigner, Lovell and Schmidt (1977) the translog technology, assuming half-normal distribution for one-sided error. The standard properties of stochastic cost frontier model are illustrated below.

A bank's cost function can be written as

$$
C=\left(Y_{\mathrm{i}}, W_{\mathrm{k}}\right)+\varepsilon_{i} \quad i=1, \ldots, n
$$

where $C$ represents total costs, $Y_{\mathrm{i}}$ represents various products or services produced, $W_{\mathrm{k}}$ represents the prices of inputs used, and $\varepsilon$ represents a random disturbance term, which allows the cost function to vary stochastically. The uncertainty in the cost function can be further decomposed as

$$
\varepsilon_{i}=u_{i}+v_{i}
$$


In Equation 2, $v$ represents random uncontrollable factors that affect total cost. The error component $u_{i}$ is assumed to be distributed independently of $v_{i}$. The term $u$, on the other hand, represents individual bank's cost deviations or errors, which are due to factors that are under the control of the bank management such as technical efficiency derived from a $N\left(0, \sigma_{u}^{2}\right)$ distribution truncated below zero i.e. $u_{i} \leq 0$

We assume that the banks use inputs, $x=\left(x_{1}, x_{2}, \ldots, x_{n}\right)$, available at fixed prices, $w=\left(w_{1}, w_{2}, \ldots, w_{n}\right)$, to produce the output $y$. For our purpose, we take the simple translog cost function envisaged as a second order Taylor's series approximation in logarithmic form to an arbitrary cost function. Incorporating the time trend, the translog cost function is written as

$$
\begin{aligned}
& \ln C=\alpha_{0}+\sum_{i} \alpha_{i} \ln Y_{i}+\sum_{k} \beta_{k} \ln W_{k}+\theta_{t} t+\sum_{k} \theta_{k t} t \ln W_{k}+\sum_{i} \theta_{i t} t \ln Y_{i}+ \\
& \frac{1}{2} \sum_{i} \sum_{j} \alpha_{i j} \ln Y_{i} \ln Y_{j}+\frac{1}{2} \sum_{k} \sum_{h} \beta_{k h} \ln W_{k} \ln W_{h}+\sum_{i} \sum_{k} \gamma_{i k} \ln Y_{i} \ln W_{k}+ \\
& \frac{1}{2} \theta_{t t} t^{2}+\varepsilon_{i}
\end{aligned}
$$

where, $\ln C=$ Natural $\log$ of total cost, $Y_{i}=i$ th output, $W_{\mathrm{k}}=k$ th input price, $\varepsilon_{i}=$ disturbance term. For a cost function to be well behaved, it must be homogeneous of degree 1 in prices for each level of output. It implies the following restrictions on the translog cost function

$$
\begin{aligned}
& \sum_{k} \beta_{k}=1 \\
& \sum_{k} \beta_{k h}=\sum_{h} \beta_{h k}=\sum_{i} \gamma_{i k}=\sum_{i} \theta_{i t}=0
\end{aligned}
$$

The symmetry on the cross-price effect implies $\alpha_{i j}=\alpha_{j i}$ and $\beta_{k h}=\beta_{h k}$

The $\log$ likelihood function for $N$ observations for the half normal distribution is written as

$$
L n=N \ln \frac{\sqrt{2}}{\sqrt{\Pi}}+N \ln \sigma^{-1}+\sum_{i=1}^{n}\left[1-F^{*}\left(\varepsilon_{i} \lambda \sigma^{-1}\right)\right]+\frac{1}{2} \sigma^{2} \sum_{i}^{n} \varepsilon_{i}^{2}
$$


where $F^{*}$ represents cumulative distribution function, and $\lambda=\frac{\sigma_{u}}{\sigma_{v}}$.

The firm specific estimates of $u_{i}$ are obtained indirectly by making use of the expected value of $u_{i}$ conditional on the composed error. This method was suggested for the half-normal and exponential distributions. To illustrate, for the half-normal distribution, the mean of the conditional distribution of $u_{i}$ given $\varepsilon$ is written as $E(u / \varepsilon)=\mu_{*}+\sigma_{*} \frac{f\left(-\mu_{*} / \sigma_{*}\right)}{1-F\left(-\mu_{*} / \sigma_{*}\right)}$, where $f$ and $F$ represent the standard normal density and cummulative normal distribution function, respectively.

where $\sigma_{*}=\sqrt{\frac{\sigma_{u}^{2} \sigma_{v}^{2}}{\sigma^{2}}}, \sigma^{2}=\sigma_{u}^{2}+\sigma_{v}^{2}$, and $\quad \sigma_{v}^{2}=\frac{\sigma^{2}}{1+\lambda^{2}}$.

\section{b. Data and Variable Construction}

We use four basic inputs for the banking sector, which are labor, deposits, occupancy cost, and operating expenses. We take two outputs, measured as loans and advances and investment. The inputs are defined as $X_{1}=$ total expenditure on salaries and other benefits, $X_{2}=$ operating cost including postage, printing, stationary charges and other expenditures, $X_{3}=$ occupancy cost including rent, taxes, insurance charges and depreciation on bank's property, and $X_{4}=$ Total Deposits. The outputs are defined as $Y_{1}=$ Loans and Advances, and $Y_{2}=$ Investment. The input Prices are defined as $W_{1}=$ total expenditure on salaries and other benefits / total deposits, $W_{2}=$ operating cost / total deposits, $W_{3}=$ occupancy cost $/$ total deposits, and $W_{4}=$ total interest paid on deposits / total deposits. Then total cost function is defined as

$C=X_{1}+X_{2}+X_{3}+W_{4} \cdot X_{4}$

As can be noticed from the above due to non-availability of data on the number of employees in the banking sector, the price of labor, $W_{1}$ is obtained by dividing total expenditure on salaries by total deposits. ${ }^{3}$

\footnotetext{
${ }^{3}$ To construct price of labor, data on the number of bank employees was not available in published form. As a proxy measure for employees, we have divided total expenditures on salaries and other benefits by total deposits. By doing so, we assume a high positive correlation between the number of employees and bank deposits. This may not be a
} 
Similarly, the prices of operating cost and occupancy cost are obtained by dividing by total deposits. Our sample includes 18 banks, which cover almost $90 \%$ of the activities performed by the banking sector. Eleven banks could not be included in our sample because they were mostly newly established banks and very short time-series of the required data. The data set used here is balanced panel data, which was another motivation for us to exclude newly established banks from the included sample. Our sample includes nine Pakistani banks, nine foreign banks and the period covered is from 1976-1996. For the purpose of estimation, we use this balanced panel data and converted it into 1980 prices using own country's GDP deflators. Estimation of indices using 1980 as the base year is also incorporated. The required time series data was obtained from the State Bank Pakistan's annual Banking Statistics of Pakistan. The data on GDP deflator was obtained from The Pakistan Economic Survey.

\section{Estimates of Technical Efficiency of Commercial Banks}

In this section, we present and discuss the empirical results of the stochastic cost frontier for Pakistani and foreign owned commercial banks operating in Pakistan.

\section{a) Maximum Likelihood Estimates of the Stochastic Cost Frontier}

Given the management structure of commercial banks with Pakistani origin vis-à-vis foreign commercial banks in Pakistan, the mean technical efficiency of Pakistani banks is generally expected to be less than the foreign commercial banks. More specifically, due to nationalization of private commercial banks in Pakistan in the early 1970s, they were managed by the public sector for most of the study period. It is common knowledge that publicly owned commercial banks have frequently been used to push the political agenda of the rulers. As a result, the problems of over employment of staff, bad loans, loan write-offs, excessive branch networks, insufficient performance incentives and political interference inefficiencies have often been reported in the Pakistani press. In contrast, the functioning of commercial banks with foreign origin was based on a highly competitive and professional management structure. Due to their strong linkages with parent banks abroad, these banks hired highly qualified professional staff and introduced market-oriented work norms. Better professional services and consistent policies rapidly increased their credibility in the eyes of Pakistani customers and profits. Hence they are expected to have more efficient cost structures than their Pakistani counter parts.

perfect measure but one of the alternatives till the time that published time series on bank employees may be available. 
To make a comparison of technical efficiency of respective subgroups of commercial banks, we maximize three log-likelihood functions to obtain technical efficiency scores. First we take the full sample, and then take subsamples of commercial banks with Pakistani and foreign origins.

The full sample is a balanced panel data of 18 commercial banks from 1976-1996, while the two sub-samples consist of data on 9 commercial banks each again from 1976-1996, but for banks with Pakistani and foreign origins, respectively. Hence we estimated three log-likelihood functions in (6). The maximum likelihood parameter estimates for the stochastic translog cost frontiers by imposing homogeneity and symmetry restrictions for the full sample as well as sub-samples of Pakistani and foreign banks are presented in Table1. We can see from Table1 that most of the estimated parameters are statistically different from zero. The estimated parameters associated with time are mostly significant in all the three models, which implies that technical change has an impact on the efficiency structure of banks. The time trend parameters, $\theta_{t}$ and $\theta_{t t}$, indicate the direction and rate of change of shift in the cost function independent of prices and outputs.

The estimated model for Table 1 is written as

$$
\begin{aligned}
& \ln C=\alpha_{0}+\sum_{i=1}^{2} \alpha_{i} \ln Y_{i}+\sum_{k=1}^{4} \beta_{k} \ln W_{k}+\theta_{t} t+\sum_{k=1}^{4} \theta_{k} t \ln W_{k}+\sum_{i=1}^{2} \theta_{t i} t \ln Y_{i}+ \\
& \frac{1}{2} \sum_{i=1}^{2} \sum_{j=1}^{2} \alpha_{i j} \ln Y_{i} \ln Y_{j}+\frac{1}{2} \sum_{k=1}^{4} \sum_{h=1}^{4} W_{k} W_{h}+\sum_{i=1}^{2} \sum_{k=1}^{4} \ln Y_{i} \ln W_{k} \\
& \frac{1}{2} \theta_{t t} t^{2}+\varepsilon_{i}
\end{aligned}
$$

with all the restrictions mentioned above in equation 5 to 6 .

In Table-1 for the full sample, $\theta_{t}$ is negative, indicating that the cost function is shifting inward independent of changes in factor prices and output, although no statistical significance could be attached to this time shift. However, $\theta_{t t}$ is positive and significant. For Pakistani banks, $\theta_{t}$ is negative and statistically significant while $\theta_{t t}$ is positive and significant, which indicates that the cost function is shifting inwardly at an increasing rate. In other words, Pakistani banks have a pattern of increasing their cost 
efficiency with the passage of time. However, negativity of $\theta_{t}$ and $\theta_{t t}$ in the case of foreign banks shows that foreign banks seem to have benefited from reduction in costs attributable to technical change at a decreasing rate during the period 1976-1996.

Table1- Maximum Likelihood Parameter Estimates for the Translog Cost Frontier, 1976-1996

\begin{tabular}{|c|c|c|c|}
\hline Parameter & Full Sample & Pakistani Banks & Foreign Banks \\
\hline \multirow[t]{2}{*}{$\alpha_{0}$} & -0.47 & -3.79 & 3.62 \\
\hline & $(-0.49)$ & $(-0.38)$ & $(0.99)$ \\
\hline \multirow[t]{2}{*}{$\alpha_{1}$} & 0.82 & 3.29 & 0.92 \\
\hline & $(2.09)^{* *}$ & $(4.07)^{* * *}$ & $(1.90)^{*}$ \\
\hline \multirow[t]{2}{*}{$\alpha_{2}$} & 1.53 & 0.24 & 0.87 \\
\hline & $(6.84)^{* *}$ & $(0.63)$ & $(3.30)^{* *}$ \\
\hline \multirow[t]{2}{*}{$\alpha_{11}$} & 0.11 & -0.38 & -0.23 \\
\hline & $(1.12)$ & $(-3.47)^{* *}$ & $(-0.95)$ \\
\hline \multirow[t]{2}{*}{$\alpha_{12}$} & -0.21 & -0.21 & 0.07 \\
\hline & $(-5.13)^{* *}$ & $(-3.03)^{* *}$ & $(0.44)$ \\
\hline \multirow{2}{*}{$\alpha_{22}$} & 0.13 & 0.37 & -0.12 \\
\hline & $(3.25)^{* *}$ & $(8.02)$ & $(-0.98)$ \\
\hline \multirow{2}{*}{$* \beta_{1}$} & 0.96 & 3.18 & 0.28 \\
\hline & $(3.21)^{* * *}$ & $(5.60)^{* *}$ & (1.34) \\
\hline \multirow[t]{2}{*}{$\beta_{2}$} & -0.12 & 0.69 & -0.02 \\
\hline & $(0.66)$ & $(3.50)^{* *}$ & $(-0.06)$ \\
\hline \multirow{2}{*}{$\beta_{3}$} & -0.49 & -1.50 & -1.51 \\
\hline & $(-1.73)^{* *}$ & $(-3.37)^{* *}$ & $(-4.01)^{* *}$ \\
\hline \multirow[t]{2}{*}{$\beta_{4}$} & 0.65 & -0.41 & 3.25 \\
\hline & $(3.34)^{* *}$ & $(-1.93)^{*}$ & $(8.67)^{* *}$ \\
\hline \multirow{2}{*}{$\beta_{11}$} & -0.27 & 0.09 & -0.23 \\
\hline & $(-5.44)^{* *}$ & $(0.69)$ & $(-5.34)^{* *}$ \\
\hline \multirow[t]{2}{*}{$\beta_{12}$} & 0.21 & -1.05 & 0.08 \\
\hline & $(5.44)^{* *}$ & $(-6.64)^{* *}$ & $(0.11)$ \\
\hline \multirow[t]{2}{*}{$\beta_{13}$} & -0.04 & 0.35 & 0.19 \\
\hline & $(-0.69)$ & $(6.26)^{* *}$ & $(1.66)^{*}$ \\
\hline \multirow[t]{2}{*}{$\beta_{14}$} & 0.10 & 0.61 & 0.03 \\
\hline & $(3.42)^{* *}$ & $(10.07)^{* *}$ & $(0.77)$ \\
\hline
\end{tabular}




\begin{tabular}{|c|c|c|c|}
\hline$\beta_{22}$ & $\begin{array}{l}-0.05 \\
(-0.72)\end{array}$ & $\begin{array}{l}0.89 \\
(8.26)^{* *}\end{array}$ & $\begin{array}{l}-0.04 \\
(-0.28)\end{array}$ \\
\hline$\beta_{23}$ & $\begin{array}{l}-0.02 \\
(-0.33)\end{array}$ & $\begin{array}{l}0.28 \\
(5.36)^{* * *}\end{array}$ & $\begin{array}{l}-0.01 \\
(0.09)\end{array}$ \\
\hline$\beta_{24}$ & $\begin{array}{l}-0.14 \\
(-5.17)^{* *}\end{array}$ & $\begin{array}{l}-0.12 \\
(-2.87)^{* *}\end{array}$ & $\begin{array}{l}0.04 \\
(0.53)\end{array}$ \\
\hline$\beta_{33}$ & $\begin{array}{l}-0.05 \\
(-1.23)\end{array}$ & $\begin{array}{l}-0.09 \\
(-3.47)\end{array}$ & $\begin{array}{l}-0.01 \\
(0.10)\end{array}$ \\
\hline$\beta_{34}$ & $\begin{array}{l}0.11 \\
(3.07)^{* *}\end{array}$ & $\begin{array}{l}-0.54 \\
(8.25)^{* *}\end{array}$ & $\begin{array}{l}-0.17 \\
(-3.58)^{* *}\end{array}$ \\
\hline$\beta_{44}$ & $\begin{array}{l}-0.07 \\
(-3.65)^{* *}\end{array}$ & $\begin{array}{l}0.06 \\
(3.39)^{* *}\end{array}$ & $\begin{array}{l}0.10 \\
(3.39)^{* *}\end{array}$ \\
\hline$\gamma_{11}$ & $\begin{array}{l}-0.29 \\
(-5.64)^{* *}\end{array}$ & $\begin{array}{l}-0.56 \\
(-5.67)^{* *}\end{array}$ & $\begin{array}{l}-0.18 \\
(-5.59) * *\end{array}$ \\
\hline$\gamma_{12}$ & $\begin{array}{l}0.20 \\
(7.58)^{* *}\end{array}$ & $\begin{array}{l}0.15 \\
(5.88)^{* *}\end{array}$ & $\begin{array}{l}0.13 \\
(5.62)\end{array}$ \\
\hline$\gamma_{13}$ & $\begin{array}{l}0.08 \\
(1.26)\end{array}$ & $\begin{array}{l}0.09 \\
(0.08)\end{array}$ & $\begin{array}{l}0.21 \\
(3.42)^{* *}\end{array}$ \\
\hline$\gamma_{14}$ & $\begin{array}{l}0.06 \\
(0.13)\end{array}$ & $\begin{array}{l}0.42 \\
(9.36)^{* *}\end{array}$ & $\begin{array}{l}-0.16 \\
(-1.64)^{*}\end{array}$ \\
\hline$\gamma_{22}$ & $\begin{array}{l}-0.18 \\
(-5.69)^{* *}\end{array}$ & $\begin{array}{l}-0.19 \\
(-4.90)^{* *}\end{array}$ & $\begin{array}{l}-0.15 \\
(-3.69)^{* *}\end{array}$ \\
\hline$\gamma_{23}$ & $\begin{array}{l}0.03 \\
(0.86)\end{array}$ & $\begin{array}{l}0.25 \\
(6.06)\end{array}$ & $\begin{array}{l}0.12 \\
(1.39)^{*}\end{array}$ \\
\hline$\gamma_{24}$ & $\begin{array}{l}-0.05 \\
(-1.73)^{* *}\end{array}$ & $\begin{array}{l}-0.21 \\
(-5.19)^{* *}\end{array}$ & $\begin{array}{l}-0.11 \\
(-1.75)^{* *}\end{array}$ \\
\hline$\theta_{t}$ & $\begin{array}{l}-0.07 \\
(-0.21)\end{array}$ & $\begin{array}{l}-0.18 \\
(-3.40)^{* *}\end{array}$ & $\begin{array}{l}-0.36 \\
(-9.30)^{* *}\end{array}$ \\
\hline$\theta_{t t}$ & $\begin{array}{l}0.04 \\
(-3.57)^{* *}\end{array}$ & $\begin{array}{l}0.08 \\
(-5.69) * *\end{array}$ & $\begin{array}{l}-0.08 \\
(-6.92)^{* *}\end{array}$ \\
\hline$\theta_{1 t}$ & $\begin{array}{l}0.01 \\
(3.40)^{* *}\end{array}$ & $\begin{array}{l}0.11 \\
(9.71)^{* *}\end{array}$ & $\begin{array}{l}0.03 \\
(5.30)^{* *}\end{array}$ \\
\hline$\theta_{2 t}$ & $\begin{array}{l}0.0002 \\
(0.004)\end{array}$ & $\begin{array}{l}-0.07 \\
(-9.07)^{* *}\end{array}$ & $\begin{array}{l}-0.04 \\
(-0.53)\end{array}$ \\
\hline$\theta_{3 t}$ & $\begin{array}{l}-0.02 \\
(-3.57)^{* *}\end{array}$ & $\begin{array}{l}-0.05 \\
(-7.28)^{* *}\end{array}$ & $\begin{array}{l}-0.02 \\
(-2.03)^{* *}\end{array}$ \\
\hline$\theta_{4 t}$ & 0.07 & -0.05 & -0.02 \\
\hline
\end{tabular}




\begin{tabular}{clll} 
& $(3.56)^{* *}$ & $(2.00)^{* *}$ & $(-1.41)^{*}$ \\
$\theta_{t 1}$ & -0.03 & -0.09 & 0.07 \\
& $(3.94)^{* *}$ & $(0.65)$ & $(4.84)^{* *}$ \\
$\theta_{t 2}$ & -0.02 & -0.04 & 0.03 \\
& $(-3.68)^{* *}$ & $(-6.39)^{* *}$ & $(-0.27)$ \\
$\sigma_{1}$ & 3.188 & 5.02 & 5.88 \\
Log-likelihood $^{\mathrm{a}}$ & $(0.56)$ & $(0.66)$ & $(0.85)$ \\
$\mathrm{N}$ & 64.87 & -276.51 & -190.91 \\
\hline
\end{tabular}

Notes: ${ }^{a}$ The convergence for the log-likelihood function was achieved after 83 iterations at 0.001 tolerance level for the full sample, after 36 iterations for the sample of Pakistani banks and after 21 iterations for the sample of foreign banks.

* Significant at the $10 \%$ leve1. ** Significant at the $5 \%$ level.

*The parameter estimates were obtained by imposing the homogeneity and symmetry restrictions in all the three models.

The $\theta_{i t}$ parameters represent the share of inputs into the total cost. $\theta_{i t}$ significant for the first, third and fourth inputs in the case of full sample implies increasing share of costs of labor and deposit and declining share of occupancy cost in the total cost which suggested that technological change in the case of the full sample was 1abor and deposits using and occupancy cost saving. However, for the Pakistani banks these parameters show that the technological change was labor using and operating cost, occupancy cost and deposits saving. In the case of foreign banks, significance of all the four parameters for $\theta_{i t}$ inputs imply increasing share of operating cost and decrease in the share of labor, occupancy cost and deposits in the total cost, which suggested that technological change for the foreign banks was operating cost using, but labor, occupancy cost and deposits saving. We also found that variations in revenue shares were inversely related to time since the cross terms between output and time (i.e., $\theta_{t 1}$ and $\theta_{t 2}$ ) were negative and statistically significant for the full sample. However, for the Pakistani banks only $\theta_{t 2}$ shows the significant result, while for foreign commercial banks variations in revenue share were directly related to time as shown by positive but significant parameters of $\theta_{t 1}$ and $\theta_{t 2}$. 


\section{b) Comparing Mean Technical Efficiencies}

The mean technical efficiency is obtained by $E\left(u_{i} / \varepsilon_{i}\right)$. Banks that are away from the cost frontier are not efficient because they incur higher cost per unit of output. Table- 2 to 4 present mean efficiency scores for the three samples calculated by using stochastic cost frontier technique along with the ranking of banks. For convenience of comparison, commercial banks are assigned ranks according to their average mean efficiency scores. We find that technical inefficiency of banks in the full sample in the individual years ranges from $70 \%$ to $90 \%$ levels. It shows the efficiency relative to the banks within the sample. Few banks have performed well and comparison of the banks included in our sample is only with those banks performing well.

For purposes of comparison, Table-2 also gives information on mean efficiency levels for different years as well as the average for the whole sample. For instance, the bottom row shows that the least technical efficiency was observed in 1995 and most technical efficiency was observed in the years 1977 and 1978. In other words, for our study period technical efficiency was highest at a 96\% level in 1977 and 1978 and lowest at a $86 \%$ level in 1995 . The last column shows the ranking of different banks, which indicates that Deutsche Bank was technically the most efficient commercial bank while the Punjab Provincial Bank for Cooperatives was least efficient. When ranking pattern is taken into account it appears that, placed at number 4, the most efficient Pakistani bank was the National Bank of Pakistan from amongst the list of 18 banks. To illustrate, these rankings indicate that had the Punjab Provincial Bank for Co-operatives been fully efficient, its costs could have been decreased by $11 \%$ per annum for the entire study period. We also find that the least efficient bank with foreign origin was American National Trust and Saving Association. As expected, technical efficiency of commercial banks with Pakistani origin were found to be much less than the banks with foreign origin. 
Table-2: Ranking of Banks Based on their Mean Technical Efficiency Scores: Full Sample, 1976-96

\begin{tabular}{|c|c|c|c|c|c|c|c|c|c|c|c|c|c|c|c|c|c|c|c|c|c|c|c|}
\hline $\begin{array}{l}\text { Banks } \\
\text { /Years }\end{array}$ & 76 & 77 & 78 & 79 & 80 & 81 & 82 & 83 & 84 & 85 & 86 & 87 & 88 & 89 & 90 & 91 & 92 & 93 & 94 & 95 & 96 & $\begin{array}{c}\text { Averag } \\
\text { e }\end{array}$ & $\begin{array}{c}\operatorname{Ran}_{\mathbf{k}} \\
\end{array}$ \\
\hline $\begin{array}{ll}\text { 1. } & \text { Deutsche } \\
\text { Bank }\end{array}$ & .98 & .98 & .9 & .94 & 7 & 8 & 1 & .98 & 8 & 6 & 7 & .96 & 6 & 4 & .93 & .92 & 1 & 1 & 1 & 34 & 6 & .974 & 1 \\
\hline $\begin{array}{l}\text { 2. American } \\
\text { Bank }\end{array}$ & .97 & .97 & .96 & 5 & .94 & .93 & .93 & .93 & 5 & .93 & .94 & .97 & .96 & .93 & .94 & .90 & .86 & .84 & .90 & .91 & .91 & .955 & 2 \\
\hline 3. African Bank & .98 & .98 & .96 & .95 & .95 & .95 & .92 & .94 & .96 & .95 & .92 & .93 & .95 & .89 & .83 & .86 & .87 & .90 & .84 & .94 & .93 & .948 & 3 \\
\hline $\begin{array}{l}\text { 4. National Bank } \\
\text { of Pakistan }\end{array}$ & .95 & .96 & .96 & .95 & .94 & .93 & .95 & .93 & .95 & .95 & .93 & .93 & .93 & .93 & .92 & .98 & .89 & .87 & .86 & .85 & .84 & .947 & 4 \\
\hline 5. Mus1 & .94 & .95 & .96 & .95 & .94 & .92 & .91 & .91 & .93 & .93 & .92 & .92 & .99 & .89 & .88 & .89 & .90 & .93 & .89 & .90 & .90 & .946 & 5 \\
\hline 6. Habi & .96 & 95 & .95 & .94 & .94 & .93 & .94 & .97 & .94 & .94 & .93 & .94 & .94 & .92 & .90 & .91 & .89 & .90 & .88 & .87 & .91 & .945 & 6 \\
\hline $\begin{array}{l}\text { 7. Allie } \\
\text { Pakis }\end{array}$ & .93 & .94 & .95 & .96 & .92 & .91 & .91 & .92 & .92 & .93 & .94 & .89 & .93 & .92 & .94 & .91 & .91 & .94 & .93 & .90 & .90 & .943 & 7 \\
\hline $\begin{array}{l}\text { 8. Federal Bank } \\
\text { for Co- } \\
\text { operatives }\end{array}$ & .97 & .95 & .95 & .95 & .94 & .96 & .95 & .95 & .98 & .80 & .86 & .72 & .75 & .95 & .98 & .97 & .96 & .98 & .96 & .98 & .98 & .942 & 8 \\
\hline 9. Unit & .95 & .96 & .96 & .95 & .94 & .93 & .94 & .93 & .94 & .93 & .94 & .93 & .91 & .90 & .89 & .89 & .87 & .87 & .85 & .84 & .82 & .933 & 9 \\
\hline $\begin{array}{l}\text { 10. Ind } \\
\text { Dev } \\
\text { Ban } \\
\text { Paki }\end{array}$ & .92 & .98 & 8 & 5 & .97 & 94 & 1 & 8 & .89 & 2 & 3 & 3 & .93 & 1 & 8 & .87 & .89 & 8 & .90 & 34 & .86 & .932 & 10 \\
\hline 11. Ban & 96 & .95 & .94 & .94 & .93 & .94 & .94 & .92 & .90 & .89 & .96 & 85 & .87 & .85 & .84 & .88 & 88 & .86 & .86 & .85 & .97 & 9 & 11 \\
\hline 12. Ban & .99 & .98 & .97 & .94 & .92 & .96 & .94 & .90 & .90 & .93 & .89 & .85 & .88 & .84 & .87 & .88 & .80 & .80 & .85 & .77 & .87 & .915 & 12 \\
\hline $\begin{array}{l}\text { 13. Stan } \\
\text { Cha } \\
\text { Ban } \\
\text { 14. Agri }\end{array}$ & .94 & .95 & .96 & .94 & .92 & .91 & .92 & .94 & .93 & .90 & .89 & .87 & .87 & .85 & .82 & .83 & .86 & .84 & .84 & .84 & .96 & .913 & 13 \\
\hline $\begin{array}{l}\text { Dev } \\
\text { Ban } \\
\text { Paki }\end{array}$ & .99 & .99 & .98 & .97 & .94 & .65 & .93 & .93 & .93 & .87 & .85 & .86 & .92 & .89 & .85 & .90 & .88 & .88 & .89 & .84 & .84 & .911 & 14 \\
\hline $\begin{array}{l}\text { 15. Alge } \\
\text { Ban } \\
\text { Netl }\end{array}$ & .98 & .96 & .97 & .96 & .94 & .91 & .89 & .86 & .87 & .85 & .87 & .87 & .85 & .90 & .85 & .77 & .81 & .78 & .91 & .85 & .97 & .90 & 15 \\
\hline $\begin{array}{l}\text { 16. Rup } \\
\text { 17. Ame }\end{array}$ & .98 & .97 & .96 & .93 & .94 & .91 & .89 & .90 & .93 & .92 & .92 & .90 & .90 & .82 & .84 & .85 & .84 & .78 & .75 & .76 & .70 & .897 & 16 \\
\hline $\begin{array}{l}\text { a1 Trust } \\
\text { ving } \\
\text { tion }\end{array}$ & .96 & .96 & .95 & .96 & .94 & .92 & .91 & .89 & .89 & .90 & .90 & .88 & .87 & .88 & .82 & .82 & .81 & .78 & .77 & .76 & .81 & (8) & 17 \\
\hline $\begin{array}{l}\text { 18. Punjab } \\
\text { Provincial Co- } \\
\text { operative Bank }\end{array}$ & .73 & .83 & .90 & .86 & .94 & .88 & .87 & .83 & .91 & .92 & .95 & .95 & .88 & .88 & .85 & .86 & .88 & .89 & .86 & .91 & .91 & .891 & 18 \\
\hline Average & .95 & .96 & .96 & .94 & .94 & .91 & .92 & .92 & .93 & .91 & .92 & .90 & .90 & .89 & .88 & .88 & .87 & .87 & .87 & .86 & .89 & .975 & \\
\hline
\end{tabular}

Note: To obtain the percentage (\%) efficiency, the efficiency scores were transformed by $1 / 1+\mu_{i}$. In this transformation the most efficient bank has a score of 1 and the least efficient has a score 0 .

Table-3: Ranking of Pakistani Banks Based on their Mean Technical Efficiency Scores, 1976-1996 
$\begin{array}{llllllllllllllllllllllll}\text { Banks /Years } & 76 & 77 & 78 & 79 & 80 & 81 & 82 & 83 & 84 & 85 & 86 & 87 & 88 & 89 & 90 & 91 & 92 & 93 & 94 & 95 & 96 & \text { Averag } & \text { Ran }\end{array}$ e $\quad \mathbf{k}$

1. National Bank of Pakistan

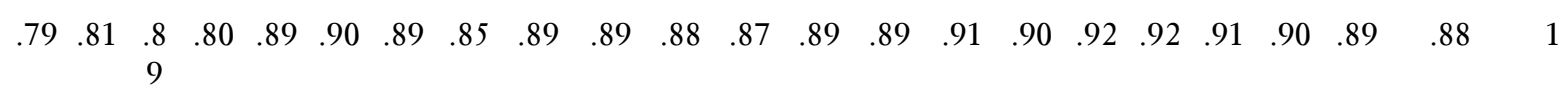

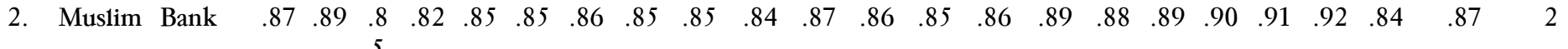

$\begin{array}{llllllllllllllllllllllllll}\text { 3. Habib Bank } & & .77 & .86 & .8 & .78 & .86 & .88 & .86 & .81 & .86 & .85 & .85 & .86 & .87 & .88 & .89 & .90 & .82 & .85 & .86 & .87 & .88 & .86 & & .86\end{array}$

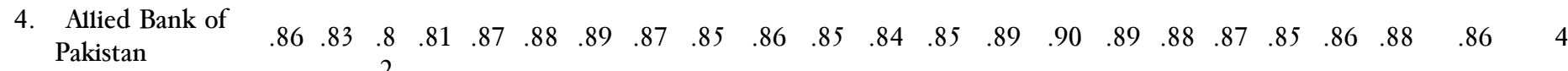

$\begin{array}{lllllllllllllllllllllllll}\text { 5. Federal Bank for } & .82 & .85 & .8 & .79 & .88 & .87 & .85 & .85 & .85 & .89 & .89 & .85 & .86 & .88 & .87 & .89 & .90 & .85 & .86 & .84 & .87 & .85 & & 5\end{array}$

$\begin{array}{lllllllllllllllllllllllllll}6 . & \text { United Bank } & & .78 & .82 & .7 & .79 & .89 & .89 & .87 & .82 & .85 & .86 & .85 & .87 & .86 & .89 & .88 & .85 & .84 & .86 & .86 & .87 & .88 & .85 & & 6\end{array}$

7. Industrial

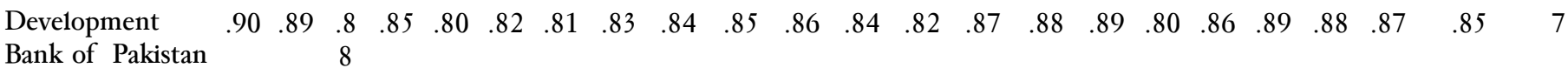

8. Agricultural Development Bank of Pakistan

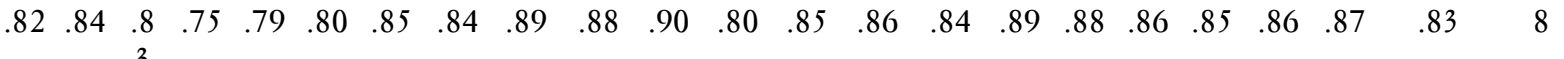

9. Punjab Provincial Cooperative Bank

Note: To obtain the percentage (\%) efficiency, the efficiency scores were transformed by $1 / 1+\mu_{i}$. In this transformation the most efficient bank has a score close to 1 and the least efficient has a score close to 0 . 
Table-4: Ranking of Foreign Banks Based on their Mean Technical Efficiency Scores, 1976-1996

\begin{tabular}{|c|c|c|c|c|c|c|c|c|c|c|c|c|c|c|c|c|c|c|c|c|c|c|c|c|}
\hline & Banks /Years & 76 & 77 & 78 & 79 & 80 & 81 & 82 & 83 & 84 & 85 & 86 & 87 & 88 & 89 & 90 & 91 & 92 & 93 & 94 & 95 & 96 & $\begin{array}{c}\text { Averag } \\
\text { e }\end{array}$ & Rank \\
\hline 1. & Deutsche Bank & .94 & .95 & .95 & .96 & .97 & .99 & .97 & .99 & .98 & .97 & .96 & .97 & .98 & .98 & .98 & .99 & .97 & .96 & .97 & .96 & .95 & .972 & 1 \\
\hline 2. & American Bank & .97 & .96 & .95 & .96 & .99 & .92 & .94 & .96 & .96 & .94 & .93 & .94 & .99 & .92 & .93 & .94 & .96 & .97 & .99 & .89 & .88 & .956 & 2 \\
\hline 3. & African Bank & .98 & .97 & .95 & .96 & .96 & .97 & .85 & .87 & .99 & .94 & .96 & .97 & .92 & .95 & .96 & .97 & .99 & .99 & .98 & .95 & .99 & .955 & 3 \\
\hline 4. & Bank of Tokyo & .98 & .98 & .98 & .98 & .98 & .98 & .98 & .98 & .98 & .98 & .98 & .98 & .98 & .98 & .96 & .94 & .87 & .88 & .88 & .86 & .86 & .954 & 4 \\
\hline 5. & Bank of India & .96 & .97 & .95 & .95 & .94 & .93 & .93 & .94 & .94 & .94 & .95 & .94 & .93 & .92 & .91 & .92 & .91 & .94 & .93 & .92 & .94 & .935 & 5 \\
\hline 6. & $\begin{array}{l}\text { Standard } \\
\text { Chartered Bank }\end{array}$ & .93 & .93 & .94 & .92 & .94 & .92 & .94 & .95 & .94 & .92 & .91 & .92 & .96 & .94 & .94 & .94 & .93 & .93 & .93 & .92 & .92 & .934 & 6 \\
\hline 7. & $\begin{array}{l}\text { Algemene Bank } \\
\text { of Netherland }\end{array}$ & .95 & .96 & .95 & .96 & .96 & .95 & .94 & .97 & .96 & .98 & .94 & .97 & .53 & .92 & .82 & .81 & .89 & .91 & .99 & .95 & .96 & .922 & 7 \\
\hline 8. & Rupali Bank & .89 & .88 & .87 & .86 & .89 & .90 & .91 & .89 & .86 & .88 & .91 & .88 & .86 & .88 & .95 & .92 & .95 & .96 & .96 & .96 & .92 & .903 & 8 \\
\hline 9. & $\begin{array}{l}\text { American } \\
\text { National Trust } \\
\text { and Saving } \\
\text { Association }\end{array}$ & .98 & .97 & .96 & .80 & .70 & .89 & .81 & .69 & .75 & .82 & .75 & .80 & .75 & .89 & .82 & .81 & .75 & .69 & .71 & .72 & .75 & .802 & 9 \\
\hline & Average & .95 & .95 & .94 & .93 & .92 & .94 & .92 & .91 & .93 & .93 & .92 & .93 & .88 & .93 & .92 & .91 & .91 & .91 & .93 & .90 & .91 & .92 & \\
\hline
\end{tabular}

Note: To obtain the percentage (\%) efficiency, the efficiency scores were transformed by $1 / 1+\mu_{i}$. In this transformation the most efficient bank has a score close to 1 and the least efficient has a score close to 0 . 
Given the difference in the nature of management practices of Pakistani and foreign banks, as discussed above, we construct separate cost frontiers for these two sub-samples and compare relative technical efficiencies of commercial banks in their respective samples. The parameters for the maximized log-likelihood functions for these two sub-samples are reported in Table-1 and discussed earlier.

In sum, commercial banks with foreign origin operate closer to their full efficiency potential than their Pakistani counterparts, which means that foreign banks are generally more cost-efficient than Pakistani banks.

\section{Summary and Conclusion}

This study was aimed at investigating empirically the technical efficiency of commercial banks operating in Pakistan and also aimed at making efficiency comparisons between the domestic and foreign banks. We have employed the parametric technique to shed light on the cost structure of banks and their nature and extent of cost inefficiency. We have derived efficiency scores by implementing a parametric translog stochastic cost frontier assuming half-normal distribution on a balanced panel data of 18 banks from 1976 to 1996 operating in Pakistan. We used the maximum likelihood estimating procedure to estimate the parameters of our models. The maximum likelihood parameter estimates for the translog cost frontier for the year 1976-1996 indicate a shift in respective cost structures of banks overtime. Our results showed that technological change occurred over time for the Pakistani banks as well as the foreign banks.

Our results indicate that the domestic banks operating in Pakistan are relatively less efficient than their foreign counterparts. This finding seems to be robust since similar ranking of included banks was obtained in all the three samples estimated in this study.

On the basis of mean efficiencies, we have found the average efficiencies and then ranked them. Ranking of the average efficiencies provides us a true picture of highly efficient banks and lowest level of efficiency of the banks. Ranking for the full sample indicates that the Deutsche Bank is relatively the most efficient bank, while the Punjab Provincial Bank for Co-operatives was about $18 \%$ inefficient per annum as compared with its full potential, and thus regarded as the least efficient bank.

Separate mean efficiency scores were also estimated for the least and most efficient banks within their own sample. The Deutsche Bank is found 
to be most efficient having $97 \%$ efficiency level and is ranked at number 1 , while the American National Trust and Saving Association is least efficient and is ranked at number 9. Similarly, the ranking of Pakistani banks reflects that the National Bank of Pakistan is relatively most efficient among the 9 Pakistani banks. While Punjab Provincial Bank for Co-operatives is found to be the least efficient.

An interesting finding of this study is that when we constructed the best practice efficiency frontier of Pakistani banks, the best and worst performers are not very far apart on that frontier. In other words, all Pakistani commercial banks need to improve their respective cost efficiencies to bring them at an overall higher level. The best performers do have a little edge over others, but even their performance is far from satisfactory.

The foreign banks appear to be less constrained than the Pakistani banks [Klien 1992]. The present system seems to waste resources by diverging from efficient allocation choices, and frequently allows resources to flow more easily in line with political priorities.

The government as owner of the banks, underwrites the resulting costs. It is felt that a more transparent market based system is needed which will improve intermediation efficiency, reduce rent seeking activities, which helps in increasing the overall cost efficiency of banks without any political interference. Strong auditing requirements and full disclosure rules for banks and other financial institutions will also be helpful in increasing the overall efficiency of banks without any political interference [Klien 1992].

Banking reforms, which have started yielding positive results, should be continued to consolidate the past gains and to further improve the efficiency of commercial banks. 


\section{References}

Aigner, D., C.A. Knox Lovell, and P. Schmidt 1977, "Formulation and Estimation of Stochastic Frontier Production Function Model", Journal of Econometrics, 6, 21-37.

Altunbas, Y., John Goddard, and Phil Molyneux 1999, “Technical Change in Banking”, Economic Letters, 64, 215-221.

Aly, H.Y., R. Grabowski, C. Pasurka, and N. Rangan 1990, “Technical, Scale and Allocative Efficiencies in US Banking: An Empirical Investigation”, Review of Economics and Statistics, 72(2), 211-217.

Anderson, A. 1993, "European Banking and Capital Markets: A Strategic Forecast”, The Economist Intelligence Unit, London.

Chang, C.E., I. Hasan, and W.C. Hunter 1998, "Efficiency of Multinational Banks: An Empirical Investigation”, Applied Financial Economics, 8, 689- 696.

Favero, C.A., and L. Papi 1995, "Technical Efficiency and Scale Efficiency in Italian Banking Sector: A Non-Parametric Approach”, Applied Economics, 27, 385-395.

Ferrier, G.D., and C.A. Knox Lovel1 1990, "Measuring Cost Efficiency in Banking: Econometric and Linear Programming Evidence”, Journal of Econometrics, 46, 229-245.

Government of Pakistan, 1999a, Pakistan Economic Survey, Ministry of Finance, Economic Advisory Wing, Islamabad.

Government of Pakistan 1999b, "Pakistan 1999, An Official Handbook on Statistics”, Federal Bureau of Statistics, Statistics Division, Islamabad, 72-80.

Klien, U.M. 1992, “Commercial Banking in Pakistan” In Anjum Nasim (ed.), Financing Pakistan's Development in the 1990s, Oxford University Press, Karachi, 387-417.

Land, K.C., C.A. Knox Love11, and S. Thore 1988, "Chance-Constrained Efficiency Analysis”, Working Paper, Department of Economics, University of Carolina, Chape1 Hill, N.C. 42, 23-36. 
Musleh-ud-Din, Ejaz Ghani, and Sarfraz K. Qureshi 1996, "Scale and Scope Economies in Banking: A Case Study of the Agriculture Development Bank of Pakistan”, The Pakistan Development Review, 35 (3), 203-213.

State Bank of Pakistan, 1976-1996, Banking Statistics of Pakistan, Karachi.

Yotopulas, A. and Lau, A. M. 1973, "Concepts and Measurement of Efficiency”, Journal of Banking and Finance, 18, 83-96.

Yuergert, A.M. 1993, "The Measurement of Efficiency in Life Insurance: Estimates of a Mixed Normal Gamma Error Model”, Journal of Banking and Finance, 17, 483-496.

Zardkoohi, and Kolari 1994, "Branch Office Economics of Scale and Scope Evidence from Saving Banks in Finland”, Journal of Banking and Finance, 18, 421-432. 